\title{
Studi Kasus: Persepsi Dan Pengalaman Mahasiswa Selama Perkuliahan Profesi Kependidikan Secara Daring
}

\author{
Yurni* \\ FKIP Universitas Batanghari \\ *Correspondence email: yurni@unbari.ac.id
}

\begin{abstract}
Abstrak. Pendapat dan pengalaman 8 orang mahahasiswa yang mengambil mata kuliah Profesi Kependidikan secara daring diteliti. Data yang diperoleh melalui teknik wawancara terfokus diteliti dengan menggunakan analisis tematik. Mahasiswa memiliki pandangan yang positif dan negatif terhadap beberapa aspek pembelajaran online. Ditemukan tiga faktor utama yang mempengaruhi mahasiswa dalam pembelajaran daring: (1) presensi sosial mahasiswa, (2) kompetensi mengajar dosen, dan (3) jaringan internet. Temuan penelitian ini diharapkan bisa meningkatkan praktek perkuliahan daring dan kualitas belajar mengajar di Perguruan Tinggi.
\end{abstract}

Kata kunci: Belajar Daring; Presensi social; kompetensi Dosen

Abstract. The opinions and experiences of 8 students who took the Education Profession course online were investigated. The data obtained through the focused interview technique were examined using thematic analysis. Students have positive and negative views on several aspects of online learning. Three main factors were found that influence students in online learning: (1) students' social presence, (2) lecturers' teaching competence, and (3) internet network. The findings of this study are expected to improve the practice of online lectures and the quality of teaching and learning in universities.

Keywords: Online Learning; social presence; Lecturer competence

\section{PENDAHULUAN}

Pandemi Covid-19 yang melanda seluruh dunia sejak tahun 2019, tak terkecuali di Indonesia mempengaruhi pelaksanaan pendidikan. Hampir semua jenjang pendidikan harus menyesuaikan pelaksanaan kegiatan belajar mengajar, melalui pembelajaran daring (Hamid dkk, 2020). Pembelajaran daring pada tingkat Perguruang Tinggi bukanlah sebuah metode baru (Mccroy, 2003). Tipe pembelajaran ini telah diterapkan pada mahasiswa yang berkuliah pada Universitas Terbuka. Namun pada mahasiswa dari kampus-kampus biasa yang di rancang untuk pertemuan tatap muka, pembelajaran daring menimbulkan beberapa dampak baik positif dan negatif.

Pembelajaran daring atau jarak jauh telah menjadi semacam inovasi di bidang pendidikan terutama pada masa Pandemi Covid-19. Mahasiswa dan dosen dipisahkan oleh jarak dan waktu dalam proses pembelajaran. Adanya internet dan berbagai program komputer mempermudah berjalannya pelaksaan pembelajaran daring secara multi modal. Pembelajaran yang menggunakan multimodal ini dianggap mampu meningkatkan proses pendidikan karena kualitasnya yang kompleks (Coman dkk, 2020).

Dosen dan mahasiswa diharuskan mampu secara efektif menggabungkan kinerja dan kolaborasi dalam proses belajar mengajar multimodal. Menurut Tham dan Werner (2005) terdapat tiga faktor yang mempengaruhi keberhasilan pembelajaran daring: (1) siswa yang mungkin merasa terisolasi karena tidak adanya rekan fisik, (2) Dosen harus mengetahui bagaimana menggunakan alat untuk meningkatkan pembelajaran serta berinteraksi dengan mahasiswa, (3) menciptakan lingkungan belajar yang nyaman dan bisa menarik perhatian mahasiswa.

Pembelajaran daring memudahkan mahasiswa mengikuti proses belajar dimanapun tanpa perlu hadir secara nyata. Sayangnya hal ini membuat mahasiswa kehilangan kehadiran sosial. Kehadiran sosial melibatkan domain afektif yang berkaitan dengan komunikasi interpersonal (Mykota \& Duncan, 2007). Kehadiran sosial merupakan sumber afektif penting untuk pembelajaran daring karena dapat menentukan tingkat interaksi belajar daring.

Starr-Glass (2011) menyebutkan ada tiga kontruksi kehadiran sosial, yaitu kedekatan, keaslian dan keintiman. (1) Kedekatan adalah jarak sosial dan psikologis yang dirasakan mahasiswa yang dipengaruhi oleh perilaku komunikasi, baik verbal maupun nonverbal (Arbaugh, 2001). (2) Keaslian atau autentik merupakan kualitas dan tingkat pengungkapan pribadi serta ekspresi diri yang asli (Starr-Glass, 2011). Keaslian merupakan keterlibatan psikologis yang menunjukkan kehadiran sosial paling tinggi, dimana individu menunjukkan perhatian, empati, merespon perasaan, memiliki kesadaran akan minat, motivasi dan pikiran orang lain. (3) Keintiman terjadi ketika kedekatan tercapai sebagai hasil dari perilaku asli dan ekspresi diri. Keintiman membentuk perilaku keterlibatan dan merupakan manifestasi paling tinggi dari presensi sosial. Pada perilaku kehadiran sosial, mahasiswa percaya bahwa tindakannya mandiri, terhubung, dan responsif terhadap 
orang lain dan orang lain menunjukkan perilaku yang responsif pula.

Dalam pembelajaran daring, dosen harus mampu menjadi instruktur yang efektif yaitu harus jenius secara teknis dan memiliki pengetahuan yang luas (Gulbahar \& Kalelioglu, 2015). Kompetensi dosen ditunjukkan dengan memiliki pengalaman dalam konteks belajar mengajar dan memiliki tingkat literasi teknologi yang tinggi (Ochogo dkk, 2016). Penguasaan literasi teknologi terlihat dari penguasaan perangkat ICT dan pengembangan konten pembelajaran daring (Nwagwu, 2020).

Teknologi informasi dan pembelajaran daring dipandang sebagai faktor penting dalam menjalankan aktifitas perkuliahan. Sebaliknya, mahasiswa harus menghadapi tantangan studi yang berfokus pada perspektif e-learning. Tantangan utama yang dihadapi mahasiswa adalah aksesabilitas, koneksivitas, dan kurangnya perangkat yang sesuai (Aboagye dkk, 2020).

Persepsi mahasiswa terkait tingkat dan kualitas interaksi dalam pembelajaran online mempengaruhi keberhasilan belajar mahasiswa (Picciano, 2002). Penelitian ini bertujuan mengungkap persepsi dan pengalaman mahasiswa yang sedang mengambil mata kuliah Profesi Kependidikan secara daring terkait faktorfaktor yang mempengaruhi pembelajaran daring.

\section{METODE}

Delapan orang mahasiswa yang mengontrak mata kuliah profesi kependidikan pada tahun akademik 2021/2022 diambil sebagai subyek penelitian ini. Mahasiswa ini diajak untuk mengikuti penelitian dan diberitahukan bahwa keterlibatan mereka tidak mempengaruhi nilai pada mata kuliah yang mereka kontrak.

Pengumpulan data dilakukan dengan cara diskusi kelompok terfokus (focus group discussion). Sebanyak tiga kali diskusi kelompok terfokus dilakukan: yang pertama sebelum perkuliahan dimulai, yang kedua pada perkuliahan kedua, dan yang ketiga pada perkuliahan keempat. Tujuan FGD yang pertama adalah untuk mengungkapkan persepsi mahasiswa akan belajar daring secara umum. Tujuan FGD yang kedua adalah untuk mendapatkan umpan balik formatif terkait perkuliahan dan mengidentifikasi masalah-masalah yang dihadapi mahasiswa. Tujuan FGD yang ketiga adalah untuk mengeksplorasi pengalaman mahasiswa selama mengikuti perkuliahan secara daring. Diskusi yang dilakukan direkam dan dicatat oleh peneliti. Diskusi dilakukan secara terbuka, namun peneliti tetap berusaha menjaga agar diskusi berjalan secara ekploratori.

\section{HASIL DAN PEMBAHASAN}

Hasil FGD yang pertama menunjukkan bahwa mahasiswa memiliki persepsi yang positif terhadap belajar daring, mereka merasa nyaman dan menerima bahwa mereka harus mengatur waktu belajar mereka lebih efektif dan efisien. Hanya 2 orang mahasiswa yang memiliki persepsi negatif terhadap pembelajaran daring, kendala terbesar yang mereka hadapi adalah susah mengontrol diri dan mengatur waktu belajar.

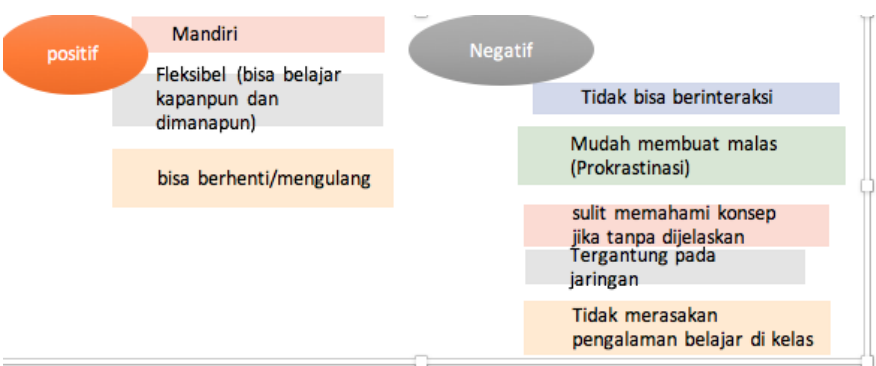

Gambar 1. Persepsi Mahasiswa Terhadap belajar Daring

Fleksibelitas menempati urutan utama sebagai atribut positif dari pembelajaran daring, baik dari segi waktu maupun tempat. Karena menurut mahasiswa, pembelajaran daring umumnya tidak mengharuskan mereka berada di kelas pada waktu tertentu sehingga mereka bisa belajar ditempat yang nyaman di rumah atau dimanapun. Fleksibelitas ini juga dikaitkan dengan persepsi positif tentang kemandirian. Mahasiswa merasa dapat memutuskan kapan dan dimana mereka bisa belajar sehingga mereka bisa mengontrol pengalaman belajar mereka. Kontrol yang bisa melakukan mencakup bisa membuat jeda, memundurkan waktu belajar, mengunjungi kembali kuliah jika diperlukan. Mahasiswa juga mempersepsi bahwa pembelajaran daring identik dengan sumber daya yang cepat sehingga memungkinkan mereka mengakses sumber daya tersebut, mereka bisa mencari bahan-bahan kuliah dari sumber-sumber yang tersedia di internet. Mahasiswa menyadari bahwa belajar daring berarti belajar mandiri.

Persepsi negatif mahasiswa yang paling utama adalah masalah presensi sosial. Ketidakhadiran teman dalam ruang belajar yang nyata membuat mereka merasa terasing sehingga malas belajar. Kehadiran teman secara nyata membuat mereka bisa merasakan kedekatan jarak sosial, mereka merasa ada untuk orang lain. Pembelajaran daring membuat mahasiswa merasa tidak bisa mengekspresikan secara nyata perasaan mereka, sehingga jika ada tugas kelompok yang ditugaskan dosen membuat mereka merasa kesulitan dan sulit bekerja sama.

Hasil FGD yang kedua ditemukan persepsi mahasiswa terhadap dosen adalah seseorang yang penting dalam pembelajaran daring, mereka merasa dosen memberikan tugas hanya untuk membuat mereka sibuk daripada memberikan pengalaman belajar yang bermakna. Menurut sebagian responden, selama pelajaran daring dosen terlihat kurang antusias dalam mengajar. Sebagian responden yang lain berpendapat dosen memiliki kemampuan mengajar yang baik dan menguasai materi. Dosen dianggap bisa menguasai media pembelajaran daring dan literasi digital sehingga mahasiswa merasa lebih mudah memahami materi.

Hasil FGD yang ketiga ditemukan pengalamanpengalaman yang dirasakan mahasiswa selama pelajaran 
daring. Pengalaman yang paling banyak mereka temui adalah kendala jaringan. Sebagian besar mahasiswa belajar dari rumah dengan lokasi rumah yang jauh dari jaringan internet kuat. Perubahan cuaca membuat kendala jaringan ini menjadi semakin buruk. Selain masalah jaringan, pembelajaran online yang menuntut pemakaian kuota internet yang cukup besar membuat sebagian besar mahasiswa yang berasal dari ekonomi sedang menjadi kesulitan. Mereka memutuskan untuk tidak selalu mengikuti pembelajaran yang memakan kuota banyak seperti Gmeet atau Zoom. Untuk mengatasi kekurangan ini, mahasiswa mengandalkan catatan kuliah yang diberikan dosen, sehingga mereka bisa membacanya kapanpun.

\section{SIMPULAN}

Kesimpulan dari hasil FGD adalah mahasiswa yang memiliki persepsi negatif terhadap pembelajaran daring memiliki kendala besar selama pelajaran. Mereka sulit mengontrol diri dan mengatur waktu belajar. Kehadiran teman merupakan faktor yang sangat diperlukan untuk memotivasi mahasiswa yang memiliki persepsi negatif terhadap pembelajaran daring, karena mereka merasakan ketidakhadiran sosial selama belajar jarak jauh. Mahasiswa yang memiliki persepsi positif akan pembelajaran daring menganggap bahwa pembelajaran daring umumnya tidak mengharuskan mereka berada di kelas sehingga mereka merasa lebih fleksibel mengatur waktu dan tempat belajar. Fleksibelitas ini dikaitkan dengan persepsi positif terhadap kemandirian belajar mahasiswa.

Kompetensi mengajar dosen ikut menentutkan persepsi positif mahasiswa. Dosen yang memiliki kemampuan mengajar dan bisa menguasai literasi digital dalam proses belajar mengajar dianggap mampu menumbuhkan motivasi belajar dan mempermudah pemahaman mahasiswa akan materi kuliah yang diberikan. Selama proses belajar daring, pengalaman yang paling banyak ditemui mahasiswa adalah kendala jaringan internet. Sebagian besar mahasiswa belajar dari rumah yang berlokasi jauh dari jangkauan jaringan internet yang stabil oleh sebab itulah sebagian mahasiswa memutuskan untuk tidak mengikuti kuliah daring. Mahasiswa ini mengandalkan catatan yang dikirimkan dosen dan penjelasan dari teman sekelas mereka.

\section{DAFTAR PUSTAKA}

Aboagye, E.; Yawson, J.A.; Appiah, K.N.(2020). COVID-19 and E-Learning: The Challenges of Students in Tertiary Institutions. Soc. Educ. Res. $1-8$.

Arbaught, J. B. (2001). How instructor immediacy behavior affect student satisfaction and learning in web-based courses. Business Communication Quarterly, 64(4), 42-54

Coman, C., Tiru, L.G., Mesesan-Schmitz, L., Stanciu, C., \& Bularca, M.C. (2020). Online Teaching and learning in higher education during the Coronavirus Pandemic: Students' Perspective. Sustainability, 12, 10367

Gulbahar, Y., \& Kalelioglu, F. (2015). Competencies for e-Instructors: How to qualify and guarantee sustainability. Contemp. Educ. Technol. 6, 140154

Hamid, R., Sentryo, I., \& Hasan, S. (2020). Online learning and Its problems in the Covid-19 emergency period. Jurnal Prima Edukasia, 8(1), 86-95

Mccroy, R.S. (2003). Online Learning in Higher Education: A review of research on interactions among teachers and students. Education, Communication \& Information, 3(2).

Mykota, D., \& Duncan, R. (2007). Learner characteristics as predictors of online social presence. Canadian Journal of Education, 30(1), 157-170.

Nwagwu, W.E. (2020). E-learning readiness of universities in Nigeria-what are the opinions of the academic staff of Nigeria's premier university? Educ. Inf. Technol. 25, 1343-1370.

Ochogo, N.K., Rambo, C.M., \& Mbwesa, J.K. (2016). Influence of Computing Competence on Lecturers' Preparedness for E-Learning at the University of Nairobi, Kenya. Bus. Educ. Accredit. 8, 53-68

Picciano, A. G. (2002). Beyond student perceptions: Issues of interaction, presence, and performance in an online course. Journal of Asynchronous Learning Networks, 6(1), 21-40

Starr-Glass, D. (2011). Beginning course surveys: Bridge for knowing and bridges for being. The International Review of Research in Open and Distance Learning, 31(5), 537-548.

Tham, C.M., \& Werner, J.M. (2005). Designing and Evaluating E-Learning in Higher Education: A Review and Recommendations. Journal of Leadership and Organization Study. 11, 15-25. 